\title{
Malignant Cell
}

National Cancer Institute

\section{Source}

National Cancer Institute. Malignant Cell. NCI Thesaurus. Code C12917.

Cells of, or derived from, a malignant tumor. 